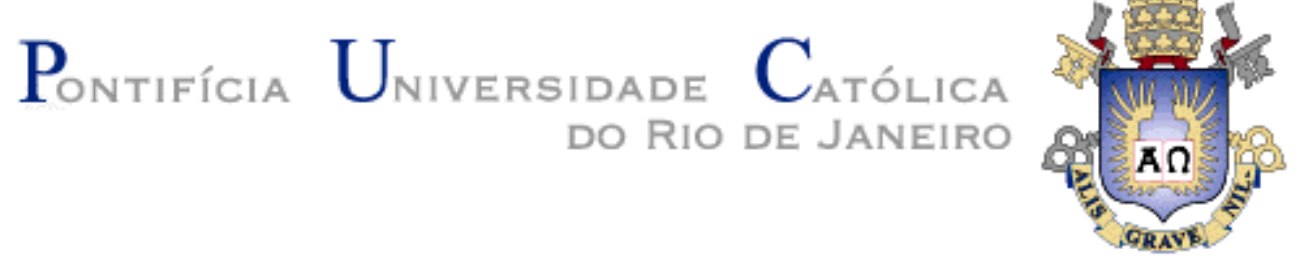

Paula Rodrigues Belem

\author{
"Para o bem do Povo e Felicidade geral da Nação." \\ Povo, Nação, Felicidade e Soberania no Dia do Fico
}

Dissertação de Mestrado

Dissertação apresentada como requisito parcial para obtenção do grau de Mestre pelo Programa de PósGraduação em História Social da Cultura, do Departamento de História da PUC-Rio.

Orientador: Prof. Ilmar Rohloff de Mattos 


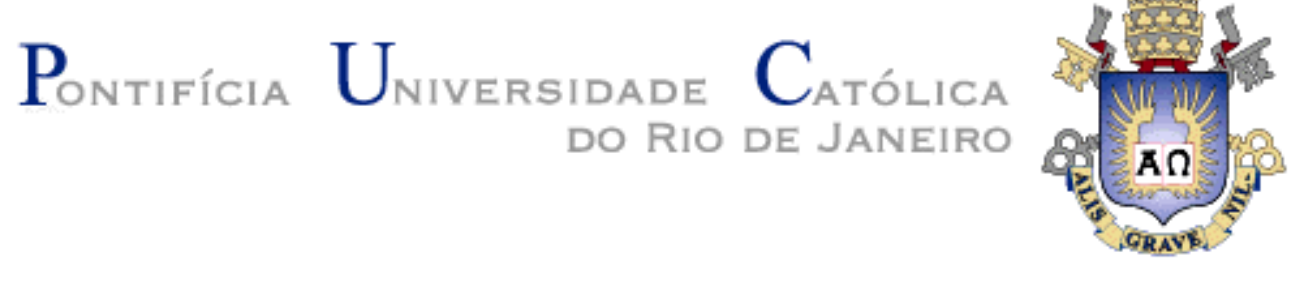

Paula Rodrigues Belem

\author{
"Para o bem do Povo e Felicidade geral da Nação." \\ Povo, Nação, Felicidade e Soberania no Dia do Fico
}

Dissertação apresentada como requisito parcial para obtenção do grau de Mestre pelo Programa de PósGraduação em História Social da Cultura do Departamento de História do Centro de Ciências Sociais da PUC-Rio.

Aprovada pela Comissão Examinadora abaixo assinada

Prof. IImar Rohloff de Mattos

Orientador

Departamento de História

PUC-Rio

Prof. Marco Antonio Villela Pamplona

Departamento de História

PUC-Rio

Prof. Marco Morel

Departamento de História

UERJ

Profa Mônica Herz

Vice-Decana de Pós-Graduação do Centro de Ciências Sociais

PUC-Rio

Rio de Janeiro, 05 de abril de 2011. 
Todos os direitos reservados. É proibida a reprodução total ou parcial do trabalho sem autorização da universidade, do autor e do orientador.

\section{Paula Rodrigues Belem}

Graduou-se em História na Pontifícia Universidade Católica do Rio de Janeiro em 2007. Concluiu a pósgraduação Lato Sensu em "História da África e do Negro no Brasil" na Universidade Cândido Mendes em 2010. É professora de História do Ensino Fundamental da rede municipal do Rio de Janeiro.

Ficha Catalográfica

Belem, Paula Rodrigues

"Para o bem do povo e felicidade geral da nação" : povo, nação, felicidade e soberania no Dia do Fico / Paula Rodrigues Belem ; orientadora: Ilmar Rohloff de Mattos. - 2011.

$139 \mathrm{f.} ; 30 \mathrm{~cm}$

Dissertação (mestrado)-Pontifícia Universidade Católica do Rio de Janeiro, Departamento de História, 2011.

Inclui bibliografia

1. História - Teses. 2. Constitucionalismo. 3. Povo. 4. Nação. 5. Soberania. 6. Felicidade. 7. Dia do Fico. I. Mattos, IImar Rohloff de. II. Pontifícia Universidade Católica do Rio de Janeiro. Departamento de História. III. Título.

CDD: 900 
Para meus pais, Paulo e Marília, minha irmã Priscila e meu companheiro eterno Bruno Eduardo. 


\section{Agradecimentos}

Agradeço à CAPES e à Puc- Rio pelo auxílio financeiro dado por meio de concessão de bolsa de estudos por um período de dois anos, que colaborou para a concretização deste trabalho. Agradeço ao professor Ilmar Rohloff de Mattos, pela orientação e pelo apoio durante a caminhada que resultou nesta dissertação. Os ensinamentos serão eternos.

Aos componentes da banca de qualificação, os professores Marco Antônio Pamplona e Marco Morel, pelas importantes sugestões e correções, que tanto contribuíram para este trabalho.

Aos meus pais Paulo e Marília pelo amor e educação. As minhas realizações são fruto dos valores e incentivos que vocês me transmitiram. A minha irmã Priscila pelo carinho e cumplicidade nos momentos mais importantes da minha vida. Ao meu namorado Bruno, pelo amor, companheirismo incondicional, pelos momentos que o dividi com os estudos. Aos meus familiares que sempre torceram por mim.

Aos meus amigos pela paciência e compreensão constantes. Obrigada, especialmente, às amigas Natália Peixoto, Mariana Lapagesse e Vanessa Barbosa.

Aos funcionários do Departamento de História da Puc-Rio, Cleusa, Cláudio, Anair, Moisés e Edna, pelo carinho e por se mostrarem sempre dispostos a ajudar no que preciso.

A todos, muito obrigada. 


\section{Resumo}

Belem, Paula Rodrigues; Mattos, Ilmar Rohloff. "Para o bem do Povo e Felicidade geral da Nação." Povo, Nação, Felicidade e Soberania no Dia do Fico. Rio de Janeiro, 2011. 139p. Dissertação de Mestrado Departamento de História, Pontifícia Universidade Católica do Rio de Janeiro.

Ao revisitar a frase "Como é para bem de todos, e Felicidade geral da Nação, estou pronto: - diga ao Povo que fico", que consagrou o Dia do Fico, este trabalho tem como objetivos: pôr em destaque o protagonismo do príncipe regente D. Pedro de Alcântara nesse acontecimento em meio às forças políticas presentes em ambos os reinos; identificar as mudanças nos conceitos Povo, Nação, Cidadão, Soberania e Felicidade em decorrência dos embates entre as concepções absolutistas do Estado e aquelas do Constitucionalismo; e dialogar criticamente com a historiografia que interpreta o Dia do Fico como o ponto de partida para “revolução de Independência do Brasil”" concretizada no 7 de setembro de 1822, uma vez que D. Pedro pretendia evitar o risco de independência e preservar a união do Império Português, garantindo a autoridade dos Braganças. Para tanto, essa dissertação traça uma pequena biografia de D. Pedro; analisa dois dos principais jornais do período o "Revérbero Constitucional Fluminense" e "A Malagueta"; e destaca a correspondência entre o príncipe e seu pai, D. João, desde fins de dezembro de 1821 até o dia 9 de janeiro de 1822, o Dia do Fico.

\section{Palavras-Chave}

Constitucionalismo; Povo; Nação; Soberania; Felicidade; Dia do Fico. 


\section{Abstract}

Belem, Paula Rodrigues; Mattos, Ilmar Rohloff. (Advisor) "For the good of the People and general Happiness of the Nation." People, Nation, Happiness and Sovereignty in the Fico Day". Rio de Janeiro, 2011. 139p. MSc. Dissertation - Departamento de História, Pontifícia Universidade Católica do Rio de Janeiro.

By revisiting the phrase "As it is for the good of everyone, and general happiness of the nation, I'm ready - tell people that I am staying", that consecrated the Fico Day, this work aims to: highlight the role of the prince regent D. Pedro de Alcântara as protagonist in this event among the political forces in both kingdoms; identify changes in the concepts of People, Nation, Citizen, Sovereignty and Happiness as a result of the clashes between the absolutist conceptions of the State and those of the Constitutionalism, and critically dialogue with the historiography that portrays the Fico Day as a starting point for "independence revolution of Brazil" achieved in the September 7, 1822., once D. Pedro intended to avoid the risk of independence and to preserve the union of the Portuguese Empire, ensuring the authority of the Braganças. To that end, this dissertation traces a short biography of D. Pedro, analyzes two of the main newspapers of the period "Revérbero Constitucional Fluminense" and "A Malagueta"; and highlights the correspondence between the prince and his father, D. João, since the end of December 1821 until January 9, 1822, the Fico Day.

\section{Keywords}

Constitutionalism; People, Nation, Sovereignty, Happiness; Fico Day. 


\section{Sumário}

1. Introdução 10

2. D. Pedro: de Príncipe do Brasil a Príncipe-Regente 17

2.1. D. Pedro e a transmigração da família real para "os Estados da América"

2.2. Uma "política de casamento": a união de D. Pedro e D. Leopoldina 25

2.3. O espírito revolucionário constitucional 27

2.4. A instrução do Príncipe 31

2.5. D. Pedro um exemplo de homem do seu século 33

2.6. A chegada das primeiras notícias da revolução constitucionalista no Reino do Brasil

2.7. A dúvida: voltaria D. Pedro para Portugal? 39

2.8. Um dia inesquecível para D. Pedro, o dia 26 de fevereiro 43

2.9. D. Pedro Regente do Reino do Brasil 50

3. Construtores de uma opinião pública: "Revérbero" e "A Malagueta" 60

4. D. Pedro, o protagonista, e os coadjuvantes do Fico 106

$\begin{array}{ll}\text { 5. Conclusão } & 130\end{array}$

6. Referências bibliográficas 133 


\section{Lista de tabelas}

Tabela 1 - Número de publicações da imprensa régia 